\title{
Socio Economic Profile of the Farmers Trained by Sardar Smruti Kendra (SSK) in Navsari District of Gujarat
}

\author{
Snehal Patel ${ }^{{ }^{*}}$ and A. P. Kanungo ${ }^{2}$ \\ ${ }^{1}$ Department of Extension Education, NMCA, NAU, Navsari, India \\ ${ }^{2}$ Department of Extension Education, COA, OUAT, Bhubaneswar, India \\ *Corresponding author
}

\begin{abstract}
A B S T R A C T
Keywords

Trained farmers, SSK

Article Info

Accepted:

07 September 2020

Available Online:

10 October 2020

India is second largest populated country in the world and also keep pace with population growth, there is a continuing need to development of the farmers. Extension system in agriculture plays very important role to disseminate information and transfer of new technology. The paper aims to study socio economic profile of the farmers trained by Sardar Smruti Kendra (SSK) in Navsari district of South Gujarat. For that one hundred twenty respondents had selected for the study. The study conclude that majority of the respondents belonged to young age group and had high school level of education. Majority of the respondents had pucca house with land holding up to 1 ha. And high level of farming experience. Majority of the respondents had low family annual income. Majority of the respondents had medium extension participation, scientific orientation and innovativeness with medium risk orientation towards Sardar Smruti Kendra.
\end{abstract}

\section{Introduction}

Agriculture is the backbone of India. More than 60-65 per cent of people depend directly or indirectly upon agriculture and allied sectors. The role of agriculture in the economic development of the India cannot be under estimated, as the largest segment of population is wedded to agriculture and it accounts for nearly half of the national income.

In agriculture production the contribution of farmer is of most importance. To enrich their skill, knowledge and competency many developmental programmes/ projects have been launched for development of farmers through introduction of up to date scientific agricultural innovation to boost agricultural production. To keep pace with population growth, there is an important to study the socio economic profile of the farmers trained by SSK towards the farming and allied activities to increase the overall production of agriculture.

The main objectives includes to study the socio economic profile of the farmers trained by SSK during last 5 years

\section{Materials and Methods}

The study was conducted in Navsari district of Gujarat purposively. Total 120 no of 
respondents were selected randomly for data collection. The data collected through structured questionnaires by face to face interview and then data were processed for further analysis. The following statistics were used in the study: Percentage, Arithmetic Mean and Standard Deviation.

\section{Results and Discussion}

Age

It is clear from the table 1 that (44.16\%) of the respondents were belonged to young age group whereas $(30.00 \%)$ and $(25.84 \%)$ of the respondents belonged to old age and middle age group respectively.

\section{Education}

The data in table 1 revealed that $(15.83 \%)$ of the respondents were illiterate, followed by $(10.83 \%)$ and $(25.84 \%)$ of the respondents can only read and write and had primary school only whereas $(42.00 \%)$ respondents had high school education and $(05.50 \%)$ went up to college and above.

\section{Housing pattern}

The data in table 1 revealed that $(11.66 \%)$ of the respondents belonged to Kaccha house followed by $(20.00 \%)$ and $(68.34 \%)$ of the respondents belonged to semi pucca and pucca house respectively.

\section{Land holding}

The data in table 1 revealed that $(32.50 \%)$ respondents had land holding up to 1 ha. Followed by $(25.84 \%)$ of the respondents had up to 1.1 to 2 ha of land holding. Whereas (28.33\%) of the respondents had 2.1 to 4 ha. of the land holding and the rest of $(13.33 \%)$ of the respondents had land holding up to above 4ha.

\section{Farming experience}

The data in table 1 revealed that $(66.66 \%)$ of the respondents had high level of farming experience followed by $(10.84 \%)$ and $(22.50 \%)$ of the respondents had medium and low level of farming experience respectively.

\section{Family annual income}

The data in table 1 revealed that $(30.84 \%)$ of the respondents had low level of the family annual income followed by $(26.66 \%)$ and $(42.50 \%)$ of the respondents had medium and high level of family annual income respectively.

\section{Extension participation}

The data in table 1 revealed that $(25.00 \%)$ of the respondents had low level of the extension participation whereas (58.34\%) and (16.66\%) of the respondents had medium and high level of extension participation in agriculture and allied sector.

\section{Scientific orientation}

The data in table 1 revealed that $(16.66 \%)$ of the respondents had low level of scientific orientation whereas $(78.34 \%)$ and $(5.00 \%)$ of the respondents had medium and high level of scientific orientation.

\section{Innovativeness}

The data in table 1 revealed that half $(55.00 \%)$ of the respondents had medium level of innovativeness followed by $(28.34 \%)$ and $(16.66 \%)$ of the respondents had low and high level of innovativeness respectively. 
Table.1 Distribution of respondents according to their socio economic profile $n=120$

\begin{tabular}{|c|c|c|c|}
\hline Sr.No & Category & Frequency & Percentage \\
\hline \multirow[t]{4}{*}{1} & Age & & \\
\hline & Young (up to 30 years) & 53 & 44.16 \\
\hline & Middle ( 31 to 50 years) & 31 & 25.84 \\
\hline & Old (above 50 years ) & 36 & 30.00 \\
\hline \multirow[t]{6}{*}{2} & Education & & \\
\hline & Illiterate & 19 & 15.83 \\
\hline & Can read and write & 13 & 10.83 \\
\hline & Primary school & 31 & 25.84 \\
\hline & High school & 51 & 42.00 \\
\hline & College and above & 6 & 05.50 \\
\hline \multirow[t]{4}{*}{3} & Housing pattern & & \\
\hline & Kaccha house & 14 & 11.66 \\
\hline & Semi pucca house & 24 & 20.00 \\
\hline & Pucca house & 82 & 68.34 \\
\hline \multirow[t]{5}{*}{4} & Land holding & & \\
\hline & Up to 1 ha. & 39 & 32.50 \\
\hline & 1.1 to 2 ha. & 31 & 25.84 \\
\hline & 2.1 to 4 ha. & 34 & 28.33 \\
\hline & Above 4 ha. & 16 & 13.33 \\
\hline \multirow[t]{4}{*}{5} & Farming experience & & \\
\hline & Low (Up to 5 years) & 27 & 22.50 \\
\hline & Medium (6 to 10 years) & 13 & 10.84 \\
\hline & High (Above 10 years) & 80 & 66.66 \\
\hline \multirow[t]{4}{*}{6} & Family annual income & & \\
\hline & Low(Up to $50,000 /$ - Rs.) & 37 & 30.84 \\
\hline & Medium(50,000 to $1,00,000 /-$ Rs. $)$ & 32 & 26.66 \\
\hline & High (Above 1,00,000/-Rs.) & 51 & 42.50 \\
\hline \multirow[t]{4}{*}{7} & Extension participation & & \\
\hline & Low level & 30 & 25.00 \\
\hline & Medium level & 70 & 58.34 \\
\hline & High level & 20 & 16.66 \\
\hline \multirow[t]{4}{*}{8} & Scientific orientation & & \\
\hline & Low level & 20 & 16.66 \\
\hline & Medium level & 96 & 78.34 \\
\hline & High level & 6 & 05.00 \\
\hline \multirow[t]{4}{*}{9} & Innovativeness & & \\
\hline & Low level & 34 & 28.34 \\
\hline & Medium level & 66 & 55.00 \\
\hline & High level & 20 & 16.66 \\
\hline \multirow[t]{4}{*}{10} & Risk orientation & & \\
\hline & Low level & 18 & 15.00 \\
\hline & Medium level & 79 & 65.84 \\
\hline & High level & 23 & 19.16 \\
\hline
\end{tabular}




\section{Risk orientation}

The data in table 1 revealed that $(65.84 \%)$ of the respondents had medium level of risk orientation followed by $(15.00 \%)$ and $(19.16 \%)$ of the respondents had low and high level of the risk orientation respectively.

It can be concluded that majority of the respondents belonged to young age group and had high school level of education. Majority of the respondents had pucca house with land holding up to 1 ha. and high level of farming experience. Majority of the respondents had low family annual income. Majority of the respondents had medium extension participation, scientific orientation and innovativeness with medium risk orientation towards Sardar Smruti Kendra. To ensure better farming experience, involvement of the farmers in training and higher level of education play key role in it.

\section{References}

Darandle, A. D. (2010). Attitude of tribal farmer towards organic farming practices in maize crop. Unpublished M, Sc. (Agri.) Thesis, AAU, Anand,

Dubey, A.K., Srivastva, J.P. and Sharma, V.K. (2008). Attitude of respondents towards KVK training programmes. Indian Res. J. Ext. Edu., 8(2/3): 5256.

Naik, R., Sundaraswamy, B. and Ansari, M. R. (2008). Attitude of farmers towards seed supplying agencies as influenced by their personal and socio-economic characteristics. Maha. J. Extn. Edu., 13: 183.

\section{How to cite this article:}

Snehal Patel and Kanungo, A. P. 2020. Socio Economic Profile of the Farmers Trained by Sardar Smruti Kendra (SSK) in Navsari District of Gujarat. Int.J.Curr.Microbiol.App.Sci. 9(10): 712-715. doi: https://doi.org/10.20546/ijcmas.2020.910.085 